\title{
Chitinophilic zoosporic fungi in various types of water bodies
}

\author{
BAZYLI CZECZUGA and ANNA GODLEWSKA \\ Department of General Biology, Academy of Medicine \\ Kilinskiego 1, PL-15-230 Bialystok 8, Poland
}

$\mathrm{Cze} \mathrm{ez}$ u a B, G od lew sk a A: Chitinophilic zoosporic fingi in various types of water bodies. Acta Mycol. 33 (1): 43-58, 1998.

Chitinophilic fungi in various types of water bodies (slough, pond, beach pool, two lakes and two rivers) were studied. Samples of water were collected every other month for hydrochemical analysis and once a month $(1992-1994)$ in order to determine the fungus content. The wings of dragonfly and flies, carapaces of crayfish and potato beetle and the fructification of two mushrooms were used as bait.

Thirty species of chitinophilic fungi were found in various types of water bodies. Chytriamyces amatans, Entophlyctis crenara, Obelidium megarrizum, Rhopalophlyctis sarcoploides, Achlya colorata, A. megasperma and Dictyuchus monosporns represent new records as chitinophilic fungi. However, Eatophlycris crenata, Obelidium megarrhizam and Padochytrium chitinophilum reported for the first time from Poland.

Key words: zoosporic fungi, chitinophilic fungi.

\section{INTRODUCTION}

Zoosporic aquatic fungi (S p a r r o w 1960) and a few species of bacteria (B e n e cke 1905; J e u n ia ux 1957; PaIuch 1973) take part in the mineralization of chitin-containing substrates in water reservoirs. Due to the presence of the enzyme-chitinase, they transform this hardly available to other organisms polysaccharide into simpler elements, ready to be mineralized by subsequent decomposers. Chitinophilic fungi use these properties to prevent excessive accumulation of deposits made by "rain of corpses" of plancton crustaceans falling to the bottom as well as water insect exuvia (S p a r ow 1937; D i c k 1970) and crayfish shell. This context, chitinophilic fungi play a significant role in aquatic ecosystems ( $R$ e is e $r$ and Fulle r 1962). 
Our preliminary investigations in this field $(\mathrm{C} \mathrm{z} \mathrm{e} \mathrm{c} \mathrm{z} \mathrm{u} \mathrm{g} \mathrm{a} \mathrm{and} \mathrm{G}$ o dle w s k a 1994) revealed the species abundant occurrence of this group of aquatic fungi in NE Poland. Therefore, we undertake to make detailed studies on chitinophilic fungi in various limnological types of water bodies mainly with regard to new chitin-containing substrates and seasonality.

\section{STUDY AREA}

The following types of water bodies were investigated: a slough, 1 pond, 1 pool, 2 lakes and 2 rivers.

Sites: 1 - the slough - this is a mirey puddle, $1 \times 0.5 \mathrm{~m}$ in dimensions, situated in the lower part of the Branicki Palace Park in which water overflowing from the fountains in the middle of the collects. Rain water from the palace roofs also collects here;

2 - the pond in the Palace Park ( 2.5 ha. max. depth to $1.75 \mathrm{~m}$ ), in which swans are bred and here wild ducks also come. In addition, erucian carp and tench are bred for anglers;

3 - the beach pool (27.2 ha. max. depth $2.5 \mathrm{~m}$ ), is located in the Dojlidy (district Biatystok) and serves as a swimming pool in summer for the habitants of the eity and for water sports. The samples were collected from the west side of this pool which the inhabitants use as a beach:

4 - Lake Biale ( 485 ha, max depth $30 \mathrm{~m}$ ), is surrounded by extensive coniferous woods of Augustow Forest. The western part of the lake is adjacent to Augustów Forest. The site for sampling was on the lake next to Recreation Centre;

5 - Lake Necko (area 518 ha, max. depth to $25 \mathrm{~m}$ ). The northern shores of the lake adjoin Augustów Forest while the south-western shores border with the town of Augustow. For this reason most of the municipal and industrial wastes of the town are drained into the lake. The sampling site was on the eastern side of the lake next to the Polish Tourist Country-Lovers' Association Centre; the shore is sandy for $1.5 \mathrm{~m}$;

6-8 - the River Biala (lenght $9.8 \mathrm{~km}$ ) - left-bank tributary of the Supraśl River flowing through Bialystok City. Three sites differing in the degree of pollution were chosen:

6 - the upper course of the Biala River, the water was the least polluted:

7 - middle of the river, the site situated in the centre Bialystok - at this site numerous drains empty the municipal and industrial wastes into the river;

8 - lower course of Biała River below the city just were the Fish Processing Plant drains wasters rich in keratin into the river:

9-11 - the River Suprasl (length $106.6 \mathrm{~km}$ ) - this is the right-bank tributary of the middle part of the Narew River, folowing through the Knyszyn Forest. The river is polluted with municipal wastes from the towns of Gródek, Michałowo, Supraśl and above all, from Białystok city (Lower course). Along a stretch of $1 \mathrm{~km}$ of the Suprast River, 3 sites were choser:

9 - above the municipal swimming pool at the sluice of an arm of the Suprast River flowing just through the town of Suprasi:

10 - situated several score meters bclow Site 9 at the municipal swimming pool and the junction of two arms of the river above the main drain of Suprasi town:

11 - below the main drain of Suprast town about $500 \mathrm{~m}$ away from Site 10. 


\section{MATERIALS AND METHODS}

In order to determine the species composition chitinophilic fungi were collected once a month in the years $(1992-1994)$. From each site one sample was taken for hydrochemical analysis (every other month) and two samples for the mycological studies. Water was collected in 5-litre Ruttner bucket from the depth at which the bucket was immersed. For the determinations of the different chemical elements in the water the methods recomended by Standard Methods (G o l t e r m a n and C I y m o 1969) were employed. For mycological analysis the water samples from each of the sites were transported in sterile glass containers of 1.51 capacity. Subsequently, in the mycological laboratory, they were placed in sterilized beakers (capacity of $0.61)$, to which the appropriate baits were added in accordance with the general principles of culture ( $\mathrm{F}$ u I le r and J a w ors k 1986). The wings of dragonflies (Aeschna juncea) and flies (Sarcophaga carnaria), carapaces of crayfish (Orconectes limosus) and potato beetle (Leptinotarsa decemlineata), and the fructification of two mushrooms (Boletus edulis and Pleurotus ostreatus were used as bait. The above materials were previously cut into small pieces, washed carefully and then boiled in a weak seap solution. Subsequently, they were rinsed thoroughly and boiled several times. The samples were kept in the laboratory for $1-2$ months and precautions were taken to ensure that the thermo-lighting conditions were as close as possible to those prevalent outside the laboratory. The fungi species were distinguished by their morphological features, measurements being made of the shreds oogonia, and oospores. Species of the chitinophilic fungi were identied using mycological keys (Johnson 1956; S parrow 1960; S y mour 1970; Batko 1975; K a rling 1977).

In order to determine the relation between the number of species fungi at a given site and various factors in the aquatic environment, statistical calculations were made. For this purpose the multiple correlation coefficient was used ( $\mathrm{Czeczuga}$ and $\mathrm{Pr}$ o b a 1987). The regression programme with a choice of variables was applied on a ODRA-1204 digital computer. The water chemistry data and aquatic fungal flora of these water bodies were processed by the average linkage method $(\mathrm{H} \mathrm{ugh}$ and $\mathrm{G} \mathrm{a} \mathrm{u} \mathrm{ch}$ 1982).

\section{RESULTS}

The results obtained indicated that the water bodies studied comprised very diversified habitats (Tab. 1). A comparative analysis of biogenic compounds (all forms of nitrogen and phosphorus) revealed the lowest 


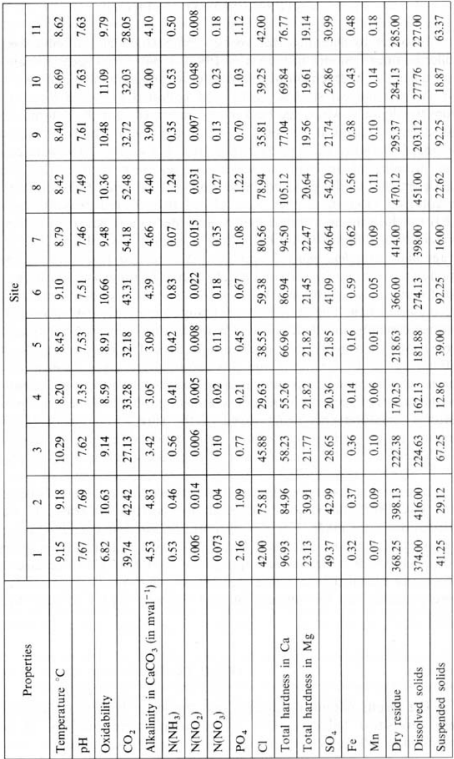


Table 2

Chitinophilic fungi found in particular bodics of water investigated

\begin{tabular}{|c|c|c|c|c|c|c|c|}
\hline Fungi & Slough & Pond & $\begin{array}{c}\text { Beach } \\
\text { pool }\end{array}$ & $\begin{array}{l}\text { Lake } \\
\text { Biale }\end{array}$ & \begin{tabular}{|c|} 
Lake \\
Niccko
\end{tabular} & $\begin{array}{l}\text { River } \\
\text { Biała }\end{array}$ & \begin{tabular}{|c|} 
River \\
Supraśl
\end{tabular} \\
\hline \multicolumn{8}{|l|}{ Chytridiomycetes } \\
\hline Allomyces arbuscula Butler & $x$ & $\mathrm{x}$ & $\mathrm{x}$ & $\mathrm{x}$ & $\mathrm{x}$ & & $\mathrm{x}$ \\
\hline Asterophlyctis irregularis Karling & & $x$ & $\mathrm{x}$ & $\mathrm{x}$ & $x$ & $\mathrm{x}$ & $\mathrm{x}$ \\
\hline $\begin{array}{l}\text { Blastocladiella britanitica Horenstein } \\
\text { in Cantino }\end{array}$ & $\mathrm{x}$ & $\mathrm{x}$ & $\mathrm{x}$ & $\mathrm{x}$ & $\mathrm{x}$ & $\mathrm{x}$ & $\mathrm{x}$ \\
\hline Blastocladiopsis parra (Whiffen) Sparrov & $\mathrm{x}$ & $x$ & $\mathrm{x}$ & $\mathrm{x}$ & $\mathrm{x}$ & $\mathrm{x}$ & $\mathrm{x}$ \\
\hline Calenaria anguillutac Sorokin & $\mathrm{x}$ & $\mathrm{x}$ & $\mathrm{x}$ & & & $\mathrm{x}$ & $x$ \\
\hline Catenopityctis rariabilis (Karling) Karling & & $\mathrm{x}$ & $\mathrm{x}$ & & & $\mathrm{x}$ & $\mathrm{x}$ \\
\hline "Chytriomyces anmulatus Dogma & & $x$ & $\mathrm{x}$ & & & $\mathrm{x}$ & \\
\hline Chytrionyyces hyalinus Karling & $\mathrm{x}$ & $x$ & $\mathrm{x}$ & $x$ & $\mathrm{x}$ & $x$ & $x$ \\
\hline "Entophlyctis crenata Karling & & & $x$ & & & $x$ & $\mathbf{x}$ \\
\hline Kariingia chitinophila Karling & $x$ & $x$ & $\mathrm{x}$ & $\mathrm{x}$ & $\mathrm{x}$ & $x$ & $x$ \\
\hline "Obelidium megarrhizum Willoughby & $x$ & & $\mathrm{x}$ & & $\mathrm{x}$ & & $x$ \\
\hline Phbctochytrum aureliae Ajello & $\mathrm{x}$ & $x$ & & & $\mathrm{x}$ & $x$ & $\mathrm{x}$ \\
\hline Phlyctorhiza endogena Hanson & $\mathrm{x}$ & $\mathrm{x}$ & $\mathrm{x}$ & $\mathrm{x}$ & $\mathrm{x}$ & $\mathrm{x}$ & $x$ \\
\hline Podochytrium chitinophiltam Willoughby & $\mathrm{x}$ & & & & $\mathrm{x}$ & $x$ & $\mathrm{x}$ \\
\hline Polychytritum aggregatum Ajello & $\mathrm{x}$ & & & & & $\mathrm{x}$ & \\
\hline Rhiziditam chitinophilum Sparrov & $\mathrm{x}$ & $\mathrm{x}$ & $\mathrm{x}$ & $x$ & $\mathrm{x}$ & $\mathrm{x}$ & $x$ \\
\hline Rhizopitlyetis petersenii Sparrov & $x$ & $x$ & $\mathrm{x}$ & & & & $\mathrm{x}$ \\
\hline Rhopalophlyctis sarcoptoides Karling & & $\mathrm{x}$ & $\mathrm{x}$ & $\mathrm{x}$ & $\mathrm{x}$ & & \\
\hline \multicolumn{8}{|l|}{ Oomycetes } \\
\hline - Adilya coloria Pringsheim & & $\mathrm{x}$ & $\mathrm{x}$ & & $\mathrm{x}$ & $\mathrm{x}$ & $x$ \\
\hline Achlya Klebsiana Pieters & & $x$ & $\mathrm{x}$ & & & $\mathrm{x}$ & $x$ \\
\hline - Achlya megasperma Humphrey & & & & & $\mathrm{x}$ & $\mathrm{x}$ & $x$ \\
\hline Achlya aligacantha de Bary & $\mathrm{x}$ & $x$ & $\mathrm{x}$ & $x$ & $x$ & $\mathrm{x}$ & $x$ \\
\hline Aplianomyces irregularis Scott & $\mathrm{x}$ & $\mathrm{x}$ & $\mathrm{x}$ & $\mathrm{x}$ & $\mathrm{x}$ & $\mathrm{x}$ & $\mathrm{x}$ \\
\hline Aphanomyces laevis de Bary & & $\mathrm{x}$ & $\mathrm{x}$ & & & $\mathrm{x}$ & $\mathrm{x}$ \\
\hline Apitanomyces stellatus de Bary & $\mathrm{x}$ & $x$ & $\mathrm{x}$ & $x$ & & $\mathrm{x}$ & $\mathrm{x}$ \\
\hline Apodachlya brachynena (Hildbr.) Pringsh. & $\mathrm{x}$ & $x$ & $\mathrm{x}$ & & & $\mathrm{x}$ & $x$ \\
\hline $\begin{array}{l}\text { Ciadolegnia unispora (Coker et Couch) } \\
\text { Johannes }\end{array}$ & & & $\mathrm{x}$ & & & $x$ & $x$ \\
\hline "Dictyuchus monosporus Leitgeb & & $\mathrm{x}$ & $\mathrm{x}$ & $\mathrm{x}$ & & $\mathrm{x}$ & $\mathrm{x}$ \\
\hline Leptoiegnia caudata de Bary & $\mathrm{x}$ & $\mathrm{x}$ & $\mathrm{x}$ & $\mathrm{x}$ & $\mathrm{x}$ & $\mathrm{x}$ & $\mathrm{x}$ \\
\hline Saprolegnia ferax (Gruith) Thurnet & $x$ & $\mathrm{x}$ & $\mathrm{x}$ & $\mathrm{x}$ & $\mathrm{x}$ & $\mathrm{x}$ & $\mathrm{x}$ \\
\hline Number of species & 19 & 24 & 26 & 15 & 18 & 26 & 27 \\
\hline
\end{tabular}

"new records of chitinophilic fungi 


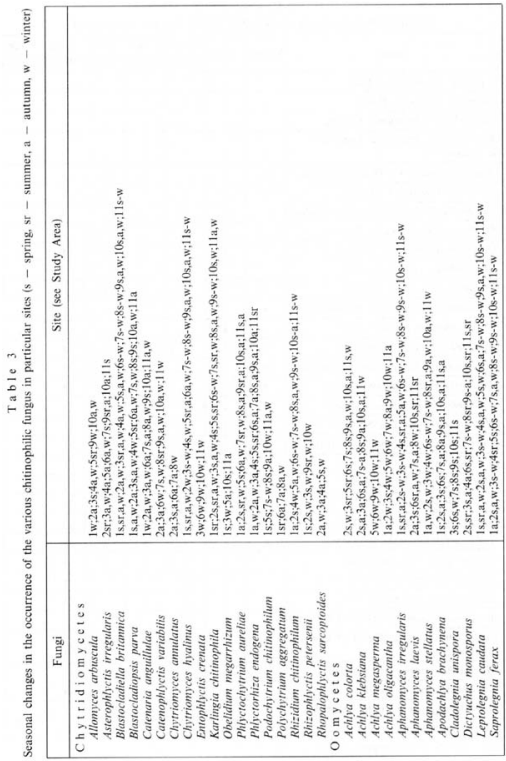


concentrations of ammonium nitrogen in the water at Site 7 (middle course of the Biala), while the highest at Site 8 (lower course of the Biala). The phosphorus concentration was the lowest at the Site 4 (lake Biale) and the highest at Site 1 (slough). The remaining parameters also varied at the respective sites.

During the two years in investigations, 30 species were observed on chitin-containing substrates, including 18 Chytridiomycetes and 12 Oomycetes species. Most chitinophilic fungi species developed in the water of the River Supraśl, Biała and beach pool whilst the fewest in lake Necko and Białe (Tab. 2). The most common species were: Blastocladiella britannica, Chytriomyces hyalinus, Karlingia chitinophila, Rhizidium chitinophilum, Aphanomyces irregularis, A. stellatus, Leptolegnia caudata and Saprolegnia ferax. Rare species included: Chytriomyces annulatus, Entophlyctis crenata, Olpidium megarrhizum, Polychytrium aggregatum, Rhopalophlyctis sarcoptoides, Achlya megasperma and Cladolegnia unispora (Tab. 3).

$\mathrm{Ta}$ a 1 e 4

Number of fungi species found on particular baits in bodies of the water investigated

\begin{tabular}{|l|c|c|c|c|c|c|}
\hline $\begin{array}{c}\text { Reservoirs } \\
\text { of water }\end{array}$ & B. edulis & P. nstreamis & A. juncea & L. decemlineata & O. limasus & S. carnaria \\
\hline Slough & 4 & 8 & 14 & 6 & 3 & 12 \\
Pond & 7 & 6 & 15 & 9 & 5 & 17 \\
Beach pool & 6 & 5 & 20 & 8 & 2 & 21 \\
Lake Biale & 3 & 2 & 10 & 2 & 1 & 6 \\
Lake Necko & 5 & 4 & 7 & 4 & 1 & 12 \\
River Biala & 16 & 11 & 23 & 11 & 7 & 21 \\
River Suprast & 13 & 12 & 25 & 13 & 11 & 21 \\
\hline
\end{tabular}

Nearly all species occurred in throught the year, while such as Entophlyctis crenata and Achlya megasperma were found only in winter months. Some fungi as Catenaria anguillae, Chytriomyces annulatus, Obelidium megarrhizum, Rhopalophlyctis sarcoptoides, Achlya oligacantha, Apodachlya brachynema and Cladolegnia unispora were not observed in summer. In all the water bodies studied most fungi developed on the wings of the dragonfly and the fly, the fewest on the shell of the crayfish (Tab. 4). Such species as Catenaria anguillulae, Catenophlyctis variabilis and Phlyctorhiza endogena were found only on the wings of dragonflies while Blastocladiella britannica, Chytriomyces hyalinus, Achlya klebsiana, A. oligacantha, Aphanomyces irregularis, A. stellatus, Dictyuchus monosporus, Leptolegnia caudata and Saprolegnia ferax were observed on all the substrates used analysis (Tab. 5). 


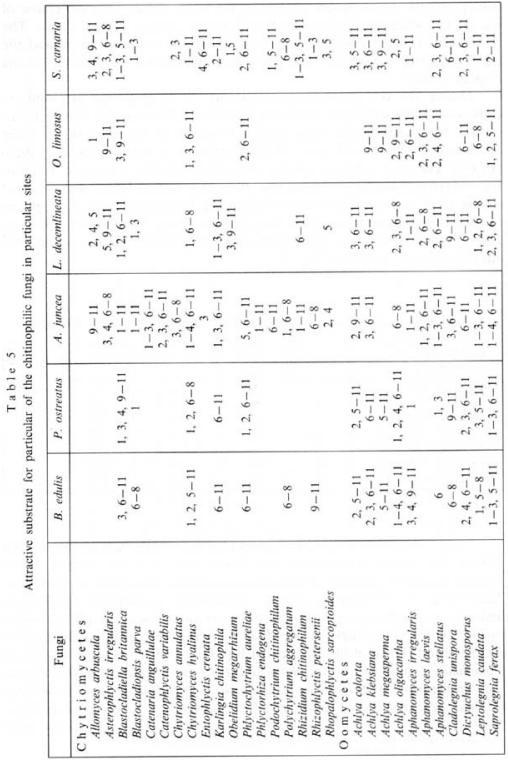




\section{DISCUSSION}

A comparative analysis of the fungi found on various vegetable and animal chitin-containing substrates and chitinophilic fungi listed in the monography by Spartow (1960) revealed that except Chytriomyces hyalinus, Phlyctochytrium aureliae, Polychytrium agregatum, Rhizidium chitinophilum and Rhizophlyctis petersenii, the remaining species complete this list. Moreover, the present data indicated the presence of fungi that grow on chitin-containing substrates and which had already been found in the waters of northeastern Poland (C z e c z u g a and G o d le w s k a 1994, $\mathrm{Cz}$ e z u g a et al. 1998). The include Chytriomyces annulatus, Entophlyctis crenata, Obelidium megarrhizum, Podochytrium chitinophilum, Rhopalophlyctis sarcoptoides, Achlya colorata, A. megasperma and Dictyuchus monosporus.

Chytriomyces annulatus was described in the United States from the vicinity of Lake Douglas by D o g m a (1969). In our case, it grew in the pond-moat, in the bathing pond and in the River Biała on the wings of dragonflies and flies. It has been hitherto found in Lakes near Elk, Sejny, in the River Narew and in forest lakes called Suchary (C z e c z u g a 1995a, b, c; 1996 a, b). Entophlyctis crenata was described as an epidermal parasite of cells of an aquatic plant Vallisneria sp. in New Zealand (K a r 1 i n g 1967). We found it on the wings on dragonflies and flies in the bathing pond in the upper course of the River Biala and at all sites of the River Supraśl, only in winter months. Obelidium megarrhizum was observed to grow in the waters of the slough, bathing pond, Lake Necko and at Site 10 in the River Supraśl. It was first described by W i 11 o u g h b y (1961a) in England in the vicinity of Lake District. The above author described Podochytrium chitinophilum from bottom sediment samples on a chitin-containing substrate. We observed $P$. chitinophilum on the wings of dragonflies and flies in the waters of the slough, Lake Necko, the River Biala and Suprasil. Among the representatives of Chytridiomycetes, a new chitinophilic fungus Rhopalophlyctis sarcoptoides, described from the waters of Brazil ( $\mathrm{K}$ a r I ing 1945). We found it to occurring on the wings of dragonflics, flics and potato beetle in the waters of both ponds and lakes. In our hitherto studies Rhopalophlyctis sarcoptoides only found in the waters of Suchar II in Suwalki province (C z e c z ug a 1995b).

Three species of Oomycetes i. e. Achlya colorata, A, megasperma, and Dictyuchus monosporus, were recognized for the first time as chitinophilic fungi. Achlya colorata developed in the ponds, Lake Necko and in the two rivers on all the substrates used for analysis, except Orconectes limosus, A. megasperma was observed only in winter months in the water of Lake Necko and in both rivers on all the substrates except dragonflies and potato beetle. These Achlya species are quite frequently encountered in inland waters ( $\mathrm{J} \circ \mathrm{h} \mathrm{n} \mathrm{s} \circ \mathrm{n} 1956$ ) 
Dictyuchus monosporus, a new species of the Oomycetes was noted on all the substrates in the ponds, rivers and in Lake Biale. It is common in the waters of the northeastern part of Poland, both in running waters and in lakes of various size ( $C \mathrm{zeczug}$ a $1991 \mathrm{a}, \mathrm{b}$; C zeczug a et al. 1997). It is recognized as a fish parasite (C z e c z u g a et al. 1995). Three species from this chitinophilic fungi, namely Entophlyctis crenata, Obelidium megarrhizum and Podochytrium chitinophilum turned of to be new to the water bodies of Poland (Fig. 1).

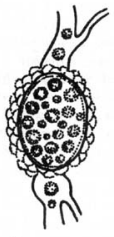

A.

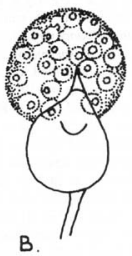

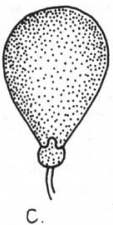

Fig. 1, Chitinophilic fungi new for Poland

A - Entoplatyctis crenata - mature resting spore with a hyaline crenate wall; B - Obelidium megarrhizam - swarming of planospores; C - Podachyuritum chitinaphilum - full grown zoosporangium with a sterile basal cell (after Karling 1977)

While studying chitinophilic fungi for the two-year period (1992-1994) at one-month intervals in seven types of water reservoirs, we did not find Aphanomyces astaci, a fungus known to cause the so-called "plague" of crayfish ( $\mathrm{S}$ c h i k o r a 1922; U n e s t a m 1965). However, we found it in the years 1986-87 in Lake Biate ( $\mathrm{C}$ z e c z u g a 1994 a) and in 1990-91 in the River Biebrza and Ełk (C z e c z g a and G o d l ew s k 1994), as well as in Suchar II in the Suwalki National Park (C ze czug a 1995b). In all the these the aforementioned species was reported from the wings of dragonflies. Aphanomyces staci is known to grow in the nervous system and limb joints of the crayfish (K o s a k ow s k 1966) and in the carapace and muscles (Czeczuga et al. 1998). This may explain why, despite possessing the chitin-decomposing enzyme-chitinase ( $\mathrm{S}$ ö derhäl1 et al. 1978), this fungus is not attracted by the chitinous shell of Orconectes limosus. In addition 


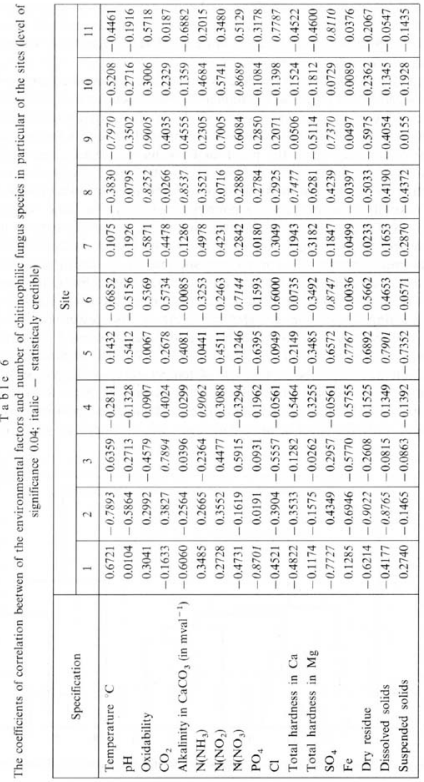


to chitinophilic fungi, crustaceans can also house a number of parasitic species (G a ertner 1962; Unestam 1966; Tracy and Vallentyn e 1969; Söderhäl I and D i ck 1991), including a common fish parasite - Saprolegnia parasitica.

Statistic elaboration of the results enabled determination of the relationships between hydro-chemical parameters at the respective sites and the number of species found at a particular site (Tab. 6). The mycoflora of the slough was affected by considerably the levels of phosphates and sulphates, showing a negative correlation. In the pond-moat, water temperature and substances dissolved in the water differed from each other significantly demonstrating a negative correlation. In the bathing pond, a positive correlation was revealed in the case of amonium nitrogen concentration, while in Lake Niecko in the case of iron and substances disolved in water, while a negative influence was exerted by the suspended material. In the rivers invesigated, different hydrochemical parameters affected the number of species at various sites of the same river. Thus, in the upper part of the River Biala, the concentrations of nitrate nitrogen and sulphates influenced the occurrence of species, demonstrating a positive correlation, while in the lower part a positive correlation was exhibited by oxidability and a negative one by alkalinity and the level of calcium significant. In the River Suprasl at Site 9 a negative correlation was displayed in the case of temperature, and a positive one with the case of oxidability and sulphates. However, at Site 10, the greatest statistically effect was exerted by sulphates and chlorides (positive correlation). At Site 11, only the effect of nitrate nitrogen was cinsiderable, which indicated

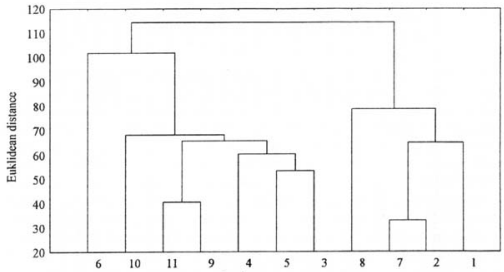

Fig 2. Clustering of sites $(1-11)$ according to number species of aquatic fungi 
that the number of fungi increased together with the concentration of this from of nitrogen. The tree diagram method showed that the number of chitinophilic fungus species in the two-year studies was the closest to oxidability of the sites investigated (Fig, 2).

The results obtained indicate that in every water body of water various hydrochemical factors affect significantly the occurrence of chitinophilic fungi, which also refered to different sites of the same water body. We noted this phenomenon while investigating phytosaprotrophes in the lakes and in the River Narew and its tributaries ( $\mathrm{Cze}$ c z u g a and P r o ba 1987), in the lakes ( $\mathrm{C} \mathrm{z}$ e c z u g a 1994 b). Similar results were obtained in the case of keratynophilic fungi in different types of water bodies $(\mathrm{C} \mathrm{z} \mathrm{e} \mathrm{c} \mathrm{z} \mathrm{u} \mathrm{g} \mathrm{a} \mathrm{and}$ Muszyńska 1994) and Hyphomycetes in different types of springs (C zeczug a and Or fow s a 1996). This was also confirmed by data obtained with the method of clustering water bodies according to water chemistry data (Fig. 3). These data showed that the same number of chitinophilic fungus species occurred at sites that differed in the chemistry of water (Fig. 4). Thus, the development of mycoflora especially chitinophilc fungi inclusive, depended on the number of environmental factors. The number of fungus species in a given water body was influenced by two groups of factors: chitinous substrate and its availability on the one hand, and chemical composition of water on the other. In the former case, the proportion of the respective parameters of water in each body of water were in constant dynamic balance. Thus, the lack of chitin-containing substrates despite favourable

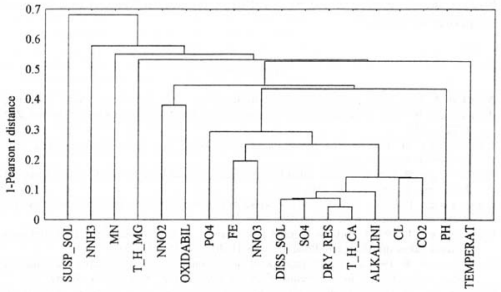

Fig. 3. Clustering of sites according to water chemistry data 


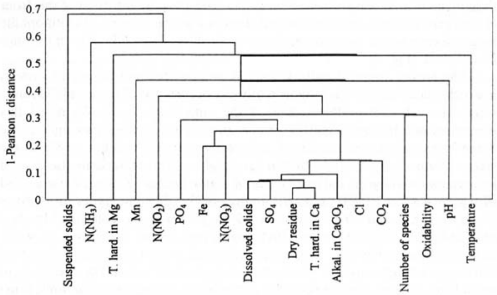

Fig. 4. Clustering of sites according to water chemistry data and to number species of aquatic fungi

aquatic conditions will limits the growth and activity of chitinophilic flora and fungi. On the other hand, environmental influence unfavourable conditions (large amount and diversity of chitin substrate) will have a negative effect on the occurrence of aquatic fungi of a given physiological group. The species composition and the activity of chitinophilic flora at a particular site in a water body is, therefore, determined by of substrate type-related factors and chemical properties of water.

\section{RFFERFNCES}

B a t k o A. 1975. Zarys hydromikologii [Hydromycology - an overeview]. PWN, Warsawa. B e n e cke W. 1905. Über Bacillus chithnororous einen Chitin zersetzenden Spait Pilz. Bot. Zeit. 8: $227-242$.

C ze c $z$ uga B. 1991 a. The mycoflora of Lake Wigry and seven adjacent lakes. Arch. Hydrobiol. 120: 495-510

C z e c z u g a B. 1991 b. Aquatic fungi in Lake Śniardwy and eighteen neighbouring lakes. Int. Revue ges. Hydrobiol. 76: $121-135$.

C z e c z u g a B. 1994 a. Aquatic fungi of twelve Augustów Lakes with reference to the chemistry of the environment. Acta Mycol. 29: 217-227.

C z e c zug a B. 1994 b. Aquatic fungi of Lake Hanicza in the Suwalki Scenic Park and some adjacent lakes (northeastern Poland). Acta Hydrobiol, 36: 371-385.

C z c czu g a B. 1995 a. Hydromycoflora of thirty-one lakes in Elk District and adjacent waters with reference to the ehemistry of the environment. Acta Mycol. 30: 49-63.

$\mathrm{Czcczuga}$ B. 1995 b. Hydromycollora fungi of small forest lakes "Suchary" in the Wigry National Park. Ibid. 30: 167-180. 
Czeczuga B. 1995 c. Mycoflora of the Narew river and its tributaries in the stretch between Tykocin and Ostroleka. Ibid. 30: 181-191.

Czeczuga B. 1996 a. Aquatic fungi in the Lake Sejny complex. Ibid. 31: 33-44.

$\mathrm{Czccz}$ u g a B. 1996 b. Aquatic fungi of the Narew river and its tributaries in the stretch from Siernianówka to Doktorce. Rocz. AM w Bialymstoku 40:85-97.

$\mathrm{Crcczuga}$ B. Godlews k a A. 1994. Aquatic fungi growing on substrates containing chitin. Acta Mycol. 29: $189-200$.

Czeczuga B., Muszy ns a E. 1994. Keratinophilic fungi in various types of water bodies, Ibid. 29: $201-215$.

Czcezuga B. Muszyńska E. Wossughi Gh., Kamaly A. Kiziew i e $z$ B. 1995. Aquatic fungi growing on the eggs of several species of acipenserid fishes. Acta Ichth. Piscat. 25: 71-79.

Czcezuga B. Muszynska E. Godlewska A. 1998. Aquatic fungi on certain species of erayfish in water from different water bodies. Pol. J. Envir. Stud. 7 : $75-82$.

Czeczuga B., Orlowska M. 1996. Hyphomycetes in twenty springs of the Knyszyn-Bialystok Forest in various seasons. Int. Revue ges. Hydrobiol. 813: 417-433.

Czeczuga B., Orlowska M., W or o n ow icz L. 1997. Fungi in water reservoirs of the western Suwalki Lake District and some adjacent water basins. Rocz. AM w Białymstoku 42: $41-61$.

Czeczuga B., Pro ba D. 1987. Mycofora of the upper part of the river Narew and its tributaries in a differentiated environment. N. Hedw. 44: 151-161.

Di e k M. W. 1970. Saprolcgniaceae on insect exuviae. Trans. Be. Mycol Soc. 55: $449-458$.

Dog m a I. J. jr. 1969. Additions to the Phycomycete flora of the Douglas Lake region. VIII. N. Hedw, 18: 349-365.

F u ll e r M. S. J a w o f $\mathrm{k}$ i J. 1986. Zoosporic fungi in teaching and research. Corporation, Athens.

G a e r t h n e r A. 1962 Cafenaria anguilluiae Sorokin als Parasit in den Embrynen von Dajplatia magna Strauss nenst Beobachtungen zur Entwicklung, zur Morphologie und zum Substratverhalten des Pilzes Arch. Mikrobiol, 43: 280-289.

Golie rm a n H. L, C I y m o R. S. 1969. Methods for chemical analysis of fresh waters L.B.P. Handbook No 8, Blackwell Sci. Publ. Oxford

$\mathrm{Hugh} \mathrm{G,} \mathrm{G} \mathrm{a} \mathrm{u} \mathrm{ch} \mathrm{jr.} \mathrm{1982.} \mathrm{Multivariate} \mathrm{analysis} \mathrm{in} \mathrm{community} \mathrm{ecology.} \mathrm{Cambridge.}$

Je un ia ux C. 1957. De quelques tests dhomogeneite appliques a une solution de chitinase microbienne purifiee. Arch. Int. Physiol 65: 135-138.

Jo h n so n T. W. 1956. The genus Achlya. Morphology and taxonomy. Ann Arbor, Michigan.

Karling J. S. 1954. Brazylian chytrids. VI Rhopaloplyctis and Chytrionyces, two ncw chitinophilic operculate genera. Amer. J. Bot. 32: 362-369.

K a r l ing J. S. 1967. Some roosporic fungi of New Zealand. VI. Entophlyctis, Diplophlyctis. Nephochytrium and Endochytrium. Sydowia 20: 109-118.

Ka $\mathrm{rling}$ J. S. 1977. Chytridiomycetarum Iconographia. J.Cramer, Vaduz.

K ossa kow sk i J. 1966. Raki. PWRiL. Warszawa.

Pa l u c h J. (ed.) 1973. Microbiology of water. PWN, Warszawa.

Reisert P. S., Fuller M. S, 1962. Decomposition of chitin by Chytriomyces species. Mycologia 54:647-657.

$\mathrm{Schik}$ or a F. 1922. Uber die Krebspest und ihren Erreger, Aphanomyces magrusi Schikora. Verh. Bot. Ver. Prov, Brandenburg 63: 87-88.

Se y mo u r R. L. 1970. The genus Saprolegnia. N. Hedw, 19; 1-124.

$\mathrm{S}$ öd e r hâl1 K., D i c k M. W. 1991. Isolation of Saprolegnia parastica from the crayfish Astacus leptodactyhes. Aquaculture 92: 121-125. 
Söd c rhäll K., S renss on E., Uncst a m T. 1978. Chitinase and protease activites in germinating zoospore cysts of a parasitic fungus, Aplianomyces astaci, Oomyceles. Mycopathol. 64: 9-11.

S par f o w F. K. 1937. Some chytridiaceous inhabitans of submerget insect exuviac. Proc.

Amer. Philos. Soc, 78: 23-53,

Sparrow F. K. 1960. Aquatic Phycomycetes. Ann Arbor. Michigan.

T r a c y S. F., V a Il e n t y n c J. R. 1969. Fungal decomposition and amino acid analysis of Mysis relicta Loven. Limnol. Oceanogr. 14: 352-356.

$\mathrm{U}$ n es t a m T. 1965. Studies on the crayfish plague fungus Aphanomyces astaci. I. Physiol. PL 18: $482-505$.

$\mathrm{U}$ n e s t a m T. 1966. Chitinolytic, cellulolytic and pectinolytic activity in vitro of some parasitic and saprophytic Oomycetes. Ibid. PI. 19: 15-30.

W i 11 o u g h b y L. G. 1961 a. Two new saprophytic chytrids from the English Lake District. Trans. Br. Mycol. Soc. 44: 177-184.

W i 11 o u g h b y L. G. 1961 b. Chitinophilic chytrids from lake muds. Ibid. 44: 586-592.

Chitynofilne grzyby pływkowe w zbiornikach wodnych różnego typu

Streszczenic

Autorzy w latach 1992 - 1994 co miesiąc badali na tle chemizmu środowiska wystepowanie chitynofilnych grzybow plywkowych w mlaku, stawie-fosic, stawie kapieliskowym, w 2 jeziorach oraz 2 rzekach. Jako przynęty używano owocników 2 gatunków grzybów kapeluszowych, pancerza raka oraz skrzydel muchy, wazkki i stonki ziemniaczanej. Na wymienionych substratach zawierajacych chitynę obserwowano rozwój 30 gatunków grzybów plywkowych.

Chyirianyces annulatus, Entophlyctis crenata, Obelidium megarluzum, Rhopalophlyctis sarcop. toides, Achlya colorata, A. megasperma oraz Diclyuchus monosporus dopetniają istnicjaca listę grzybów chitynofilnych. Dwa z nich, Entophtyclis crenata, Obelidium megarrhizum, a także Podochytrium chitinophilhm są gatunkami zarejestrowanymi po raz pierwszy w Polsce. 